J. Clin. Chem. Clin. Biochem.

Vol. 20, 1982, pp. 119-121

\title{
On the Effects of Ambilhar on Mobilisation and Biliary Excretion of Mercury
}

\author{
By F. T. Abdel Aziz, Y. Y. Al-Tamer, A. D. Bashi
}

Department of Medical Biochemistry, Medical College, Mosul University and

\section{S. Abdel-Rahim}

Department of Analytical Chemistry, Science College, Mosul University, Mosul, Iraq

(Received May 6/September 29, 1981)

Summary: The effects of administration of ambilhar to rats poisoned with mercury for two weeks were investigated. The results showed that administration of ambilhar to rats dosed with mercuric chloride, resulted in a significant increase in the faecal excretion of mercury. At the same time a significant decrease in the urinary output of the metal was found. Chelation of ambilhar with mercury to form a polar complex with a higher molecular weight could explain its biliary rather than its urinary excretion. The spectral studies of ambilhar and its two mercury complexes prepared in vitro support the possibility that stimulation of mercury excretion in bile results from the complexation of mercury by ambilhar in vivo.

Wirkung von Ambilhar auf die Mobilisierung von Quecksilber und seine Ausscheidung mit der Galle.

Zusammenfassung: Die Wirkung von Ambilhar auf Ratten, die zwei Wochen lang eine Quecksilberchlorid enthaltende Diät erhielten, wurde untersucht. Die Behandlung mit Ambilhar bewirkte einen signifikanten Anstieg der Quecksilberausscheidung in den Faeces, Gleichzeitig fiel die Ausscheidung von Quecksilber im Harn. Die Chelatbildung von Quecksilber mit Ambilhar zu einem polaren Komplex mit höherem Molekulargewicht könnte die bevorzugte Ausscheidung über die Galle gegenüber der mit dem Harn erklären. Spektrophotometrische Untersuchungen von Ambilhar und seiner zwei in vitro präparierten Quecksilberkomplexe unterstützen die Möglichkeit, daß die Quecksilberausscheidung mit der Galle durch Komplexbildung von Quecksilber mit Ambilhar in vivo gefördert wird.

\section{Introduction}

Earlier studies on the antibilharzial drug ambilhar revealed its metal ligating ability. Salah et al. (1) and Abdel Aziz et al. (2) demonstrated the excretion of iron in the urine of man and animals after administration of the drug.

Similar effects of ambilhar on body calcium and magnesium (3) and lead excretion (4) were reported: The latter finding on lead excretion was explained by the . formation of lead-ambilhar complex in vivo, which resulted in lead mobilisation and excretion.

An ideal selective antidote for mercury poisoning has not yet been found. $D, L$-penicillamine and its $\mathrm{N}$-acetyl derivative and dimercapto-propanol (BAL) form stable complexes with mercury. Most of these antidotes are toxic and still need more clinical evaluation. (5)

Our present study deals with the formation of mercuryambilhar complexes in vitro. In addition, the ability of this drug to stimulate mercury excretion was investigated.

\section{Materials and Methods}

\section{In vivo investigations}

Eight Wistar albino rats, average body weight $200-250 \mathrm{~g}$, were used in this study. They were fed a commercial diet prepared in the college animal house. They were divided into 4 equal groups in 4 metabolic cages.

\section{Mercury poisoning}

Mercuric chloride was mixed in a mortar with two kilograms of the diet, so that each gram of the diet contained $0.1 \mathrm{mg}$ mercury. Rats were fed this diet for a period of two weeks. The daily dose of mercury for each animal was calculated to be between 1.5 and two mg. Each day the urine as well as the faecal excretion of each group was separately collected for mercury estimation.

Administration of ambilhar after mercury poisoning

Ambilhar (niridazole or nitrothiazole) was mixed with two kilograms of the same diet in the animal house, so that each 
gram contained about $0.5 \mathrm{mg}$ of the drug. Administration of this was continued for 14 days starting just after the last day of mercury poisoning of the same groups of animals. The urine and faecal matter of each groups was separately collected for mercury estimation.

\section{Estimation of the mercury content of the collected samples}

A suitable weight of the dried faecal matter $(5 \mathrm{~g})$ of each group was mixed with $10 \mathrm{ml} 500 \mathrm{~g} / \mathrm{kg}$ nitric acid (Analar), gently heated over a small flame until foaming ceased, then gently boiled for about 30 minutes. The solution was left for 24 hours at $4^{\circ} \mathrm{C}$ and filtered to produce a clear extract, which was used at ${ }^{\circ} \mathrm{Cans}$. Estimation of the mercury content of the clear urine as well as the faecal extracts was performed using the Atomic Absorption Spectrophotometer (Varian Techtron AA-5). All measurements were made with the most sensitive known line of the metal, using a hollow cathode lamp and an R 213 photomultiplier. Aqueous solutions were used together with the appropriate recommended fuel support combination and burner. Wavelength was $253.65 \mathrm{~nm}$, slit width $10.0 \mathrm{~nm}$, lamp current $3 \mathrm{~mA}$.

Sensitivity of the Techtron AA-5 is $2 \mathrm{mg} / 1$. The flame fuel is air acetylene mixture. A standard calibration curve was prepared, using standard mercuric nitrate solution ( $100 \mathrm{mg} / \mathrm{l})$. A linear standard curve with the concentrations of $2.5,5,10,15,20,30$, $40 \mathrm{mg} / \mathrm{l} \mathrm{Hg}$ respectively was obtained. The concentrations of mercury in all samples were calculated according to the adjusted conditions and operational procedure of the machine. The mercury content of solutions was determined by first spraying the solution into a flame, then measuring the mercury vapour in the exhaust gases with the Techtron mercury vapour meter.

\section{Preparation of ambilhar mercury complexes in vitro}

One mmol pure crystalline ambilhar (Ciba-Geigy Labs.) was mixed with one mmol mercury $\left(\mathrm{HgCl}_{2}\right), 2$ mmol sodium metabisulphite and one mmol sodium hydrogencarbonate. The whole mixture was pulverized in a mortar, suspended in $50 \mathrm{ml}$ distilled water and left at room temperature for 48 hours. The resulting clear solution was concentrated to about $10 \mathrm{ml}$ in a boiling water bath and refrigerated for 24 hours. A dark coloured crystalline compound was precipitated. This was separated by centrifugation, dissolved in $5 \mathrm{ml}$ distilled water and applied to an alumina column $(2.5 \times 15 \mathrm{ml})$ and eluted with $600 \mathrm{ml} / \mathrm{l}$ ethanol. The eluate was concentrated in a waterbath to about $10 \mathrm{ml}$ and left at room temperature for 24 hours, where a dark crystalline compound ( $10 \mathrm{mg}$ ) was obtained. An aqueous solution of this compound was subjected to paper chromatography, using ethanol, ammonia, water $(60 \mathrm{ml}+10 \mathrm{ml}+30 \mathrm{ml})$, and methanol, acetic acid, water $(60 \mathrm{ml}+10 \mathrm{ml}+30 \mathrm{ml})$. In both systems it migrated as a single spot with $R_{\mathrm{f}}$ values of 0.8 \& 0.9 respectively. The ultraviolet spectrum of an aqueous solution of this complex was determined and compared with that of ambilhar. A sample of $8 \mathrm{mg}$ was sent to Alfred Bernhardt Labs., West Germany, for determination of mercury and molecular weight (compound A).

The experiment was repeated using $2 \mathrm{mmol}$ sodium metabisulphite and one mmol ambilhar, but with two mmol mercury $\left(\mathrm{HgCl}_{2}\right)$ and two mmol sodium hydrogencarbonate. The whole mixture was warmed in a water-bath for 20 minutes at $75^{\circ} \mathrm{C}$. A clear solution was obtained. This was filtered and left at room temperature for 72 hours. The resulting yellow-crystalline compound was dissolved in $25 \mathrm{ml} 500 \mathrm{ml} / 1$ ethanol, filtered and concentrated in a boiling water bath to about $7.5 \mathrm{ml}$. After 72 hours at room temperature yellow crystalline needles were deposited, which became dark coloured after 24 hours at the same temperature. Purity was tested as for the first complex in the same solvent systems; a single spot was observed on the chromatograms. About $8 \mathrm{mg}$ sample was sent to West Germany (Alfred Bernhardt Labs) for microanalysis, and determination of mercury content. $R_{f}$ values of this complex (Compound $B$ ) in the two systems were $0.4 \& 0.5$ respectively.

\section{Results}

Table 1.demonstrates the effect of administration of ambilhar on the faecal and urinary excretion of mercury in rats. A significant increase in faecal excretion of the metal by the drug was found, reaching a maximum after 10 days. At the same time a significant decrease in the urinary excretion of mercury can be obșprved.

Tab. 1. Effects of administration of ambilhar on the urinary and faecal excretion of mercury in rats. Means of six different mercury contents of each sample, using six different volumes.

\begin{tabular}{|c|c|c|c|c|}
\hline \multirow[t]{3}{*}{$\begin{array}{l}\text { Group } \\
\text { of rats }\end{array}$} & \multicolumn{2}{|c|}{$\begin{array}{l}\text { Rats dosed } \\
\text { with mercury }\end{array}$} & \multicolumn{2}{|c|}{$\begin{array}{l}\text { Rats dosed with } \\
\text { ambilhar after mercury }\end{array}$} \\
\hline & $\begin{array}{l}\text { Total } \\
\text { urinary } \\
\text { mercury }\end{array}$ & $\begin{array}{l}\text { Total } \\
\text { faecal } \\
\text { mercury }\end{array}$ & $\begin{array}{l}\text { Total } \\
\text { urinary } \\
\text { mercury }\end{array}$ & $\begin{array}{l}\text { Total } \\
\text { faecal } \\
\text { mercury }\end{array}$ \\
\hline & $\begin{array}{l}\bar{x}( \pm S D) \\
(\mathrm{mg})\end{array}$ & $\begin{array}{l}\bar{x}( \pm S D) \\
(\mathrm{mg})\end{array}$ & $\begin{array}{l}\overline{\mathrm{x}}( \pm \mathrm{SD}) \\
(\mathrm{mg})\end{array}$ & $\begin{array}{l}\overline{\mathrm{x}}( \pm \mathrm{SD}) \\
(\mathrm{mg})\end{array}$ \\
\hline $\begin{array}{l}\text { After } \\
3 \text { days }\end{array}$ & $\begin{array}{c}1.4 \\
\pm(0.2)\end{array}$ & $\begin{array}{c}0.4 \\
\pm(0.1)\end{array}$ & $\begin{aligned} & 0.35 * * \\
\pm & (0.04)\end{aligned}$ & $\begin{array}{l}1.10^{* * *} \\
\pm(0.1)\end{array}$ \\
\hline $\begin{array}{l}\text { Subsequent } \\
4 \text { days }\end{array}$ & $\begin{array}{c}1.2 \\
\pm(0.12)\end{array}$ & $\begin{array}{c}0.4 \\
\pm(0.1)\end{array}$ & $\begin{array}{c}1.4 \\
\pm(0.3)\end{array}$ & $\begin{array}{c}2.6^{* *} \\
\pm(0.1)\end{array}$ \\
\hline $\begin{array}{l}\text { Subsequent } \\
3 \text { days }\end{array}$ & $\begin{array}{c}1.2 \\
\pm(0.12)\end{array}$ & $\begin{array}{c}0.38 \\
\pm(0.04)\end{array}$ & $\begin{array}{r}0.8^{*} \\
\pm(0.2)\end{array}$ & $\begin{array}{l}3.2 * * \\
\pm(0.5)\end{array}$ \\
\hline $\begin{array}{l}\text { Subsequent } \\
4 \text { days }\end{array}$ & $\begin{array}{c}1.1 \\
\pm(0.1)\end{array}$ & $\begin{aligned} & 0.50 \\
\pm & (0.04)\end{aligned}$ & $\begin{aligned} & 0.40 * * \\
\pm & (0.2)\end{aligned}$ & $\begin{array}{r}0.70 \\
\pm(0.2)\end{array}$ \\
\hline
\end{tabular}

* Significant at $5 \%$ level of probability.

** Significant at $1 \%$ level of probability.

It is evident from table 2 that ambilhar in alkaline medium and in the presence of heat and sodium metabisulphite can ligate two mercury atoms per one mol of drug (B), while at room temperature with a lower concentration of $\mathrm{Hg}$, and decreased alkalinity it ligates only one atom of mercury (A).

Tab. 2. Mercury content and ambilhar mercury chelation ratio of the complexes prepared in vitro. (A \& B).

\begin{tabular}{|c|c|c|c|}
\hline \multirow[t]{2}{*}{ Complex } & \multirow[t]{2}{*}{ Mercury fraction } & \multicolumn{2}{|c|}{ Chelation ratio } \\
\hline & & $\begin{array}{l}\text { Ambilhar } \\
\text { molecule }\end{array}$ & $\begin{array}{l}\text { Mercury } \\
\text { atom }\end{array}$ \\
\hline $\begin{array}{l}\mathbf{A} \\
\hat{\mathbf{B}}\end{array}$ & $\begin{array}{l}0.5144^{*} \\
0.6284^{*}\end{array}$ & $\begin{array}{l}1 \\
1\end{array}$ & $\begin{array}{l}1 \\
2\end{array}$ \\
\hline
\end{tabular}

* Mercury estimation was performed in West Germany (Alfred Bernhardt Labs).

The absorption spectra of ambilhar and its in vitro prepared complexes with mercury are shown in figure 1.

\section{Discussion}

It can be seen from table 1 that administration of ambilhar to rats poisoned with mercury resulted in a 


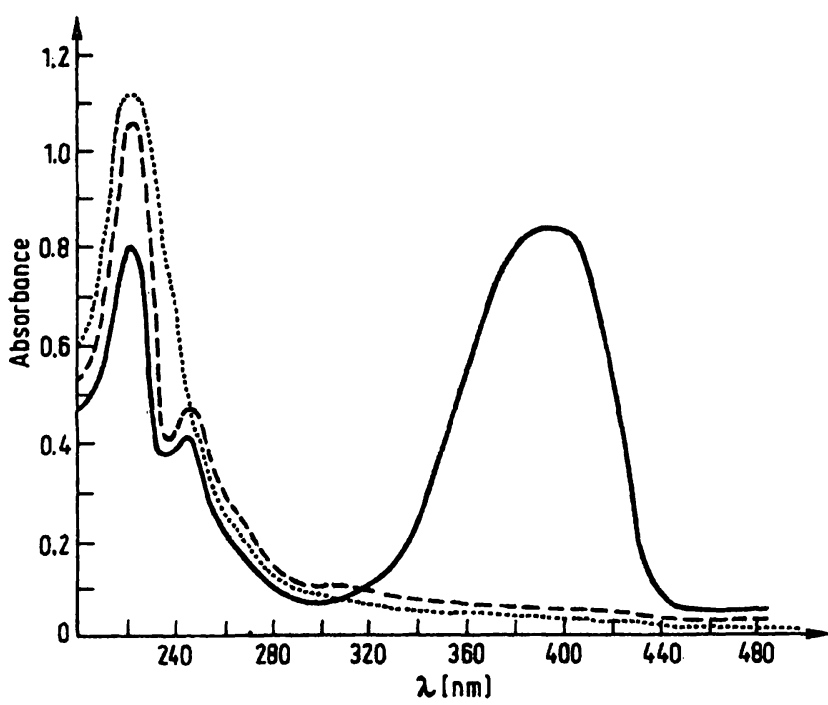

Fig. 1. Ultra violet spectra of ambilhar (-) and its in vitro prepared complexes with mercury A (-- ) and B $(\cdots . .$.$) . Disappearance of the peak at 380 \mathrm{~nm}$ in the drug after addition of mercury and the reducing agent (sodium metabisulphite) indicates the formation of an ambilhar mercury complex. Involvement of the thiazole ring of the drug in this chelation is also indicated $(380 \mathrm{~nm})$.

significant increase in faecal excretion of the metal, with a concomitant decrease in its urinary elimination.

A total of $7.617 \mathrm{mg}$ mercury were excreted in the bile in two weeks when ambilhar was administered. In the control animals this value was only $1.71 \mathrm{mg}$. On the other hand a total of $2.927 \mathrm{mg}$ of mercury were excreted in the urine in two weeks with administration of the drug. In the control animals this value was $4.875 \mathrm{mg}$. These results show the strong effect of ambilhar as a stimulant for mercury excretion in bile via the intestine.

Mobilisation of mercury by ambilhar could be explained as the result of the in vivo ligation. The mercury ambilhar complexes prepared in vitro (figs. 2,3 ) and the ability of the drug to form chelates with other metals $(1-4)$ support our conclusions. The increase in biliary excretion of mercury during administration of ambilhar is supporting evidence for an in vivo chelation of the drug with the metal, because polar compounds of higher<smiles>NC1CNC2C1=S(O)OC1NCCN12</smiles>

Fig. 2. Proposed chemical structure of the in vitro prepared ambilhar mercury complex A. It shows that one mol of ambilhar can ligate one atom of mercury. The fraction of mercury in this complex is 0.515 ; the results of microanalysis showed 0.5144 . Evidence was obtained for the role of thiazolyl sulphur in metal ligation.<smiles>NC1NCC2NCC12</smiles>

Fig. 3. Proposed chemical structure of the in vitro prepared ambilhar mercury complex B. Heat and increased mercury concentration result in a cleavage of the imidazolidinone ring. The frâction of mercury in this complex is 0.6306 ; while microanalysis showed 0.6284 .

molecular weight are excreted via the bile rather than the urine (6). Thus, chelation of ambilhar with mercury to form a cheTate of high molecular weight (more than 400 ) is followed by its biliary excretion.

The in vitro preparation of two mercury ambilhar complexes with a fraction of 0.5144 and 0.6284 mercury, respectively, suggests that two different chelates could also be formed in vivo.

Disappearance of the peak at $380 \mathrm{~nm}$ in ambilhar after the addition of mercury and sodium metabisulphite (fig. 1) could be explained by the possible involvement of the thiazole ring of the drug in the chelation process. Since the ability of the drug to ligate with mercury in vitro requires reduction it could be inferred that ambilhar is also reduced in vivo before ligation with the metal (10).

Our observation therefore suggest the use of ambilhar as an antidote for mercury poisoning. It would be safer than other mercury antidotes and its side effects would be fewer.

\section{References}

1. Salah, M. K., Hammady, I. M., Ahmed, M. Y. \& Abdel Aziz, F. T. (1970) Zentralbl. Veterinärmed. Reihe, A, 17, 257260.

2. Abdel Aziz, F. T., Al-Mallah, A. K. \& Hassanein, R. R. (1976) Zentralbl. Veterinärmed. Reihe, A, 23, 475-478.

3. Al-Khayat, T. M. N., Abdel Aziz, F. T., Izzat, N. N. \& Salah, M. (1978) J. Clin. Chem. Clin. Biochem. 16, 11-13.

4. Al-Khayat, T. M. N. \& Abdel Aziz, F. T. (1981) J. Clin. Chem. Clin. Biochem. 19, 21-23.

5. Arena, J. M. (1979) Poisoning, pp. 147-148, Charles C. Thomas, Publ., Springfield, Illinois, U.S.A.

6. Abdel Aziz, F. T., Hirom, P. C., Milburn, P. Smith, R. L. \& Williams, R: T. (1971) Biochem. J. 125, 25-26 p.

7. Abu El-Makarem, M. M., Milburn, P., Smith, R. L. \& Williams, R. T. (1967) Biochem. J. 105, 1289.

8. Milburn, P., Smith, R. L. \& Williams, R. T. (1967) Biochem. J. 105,1275 .

9. Smith, R. L. (1970) Proc. Rur. Soc. Study of Drug Toxicity, vol. 11, p. 19.

10. Kochli, H. W., B. Wermuth \& von Wartburg, J. B. (1980) Bioch. Biophys. Acta 616, 133-142.

Dr. F. T. Abdel Aziz Dr. Y. Y. Al-Tamer Medical Biochemistry Dept. Medical Coll. Mosul Univ. Mosul, Iraq 


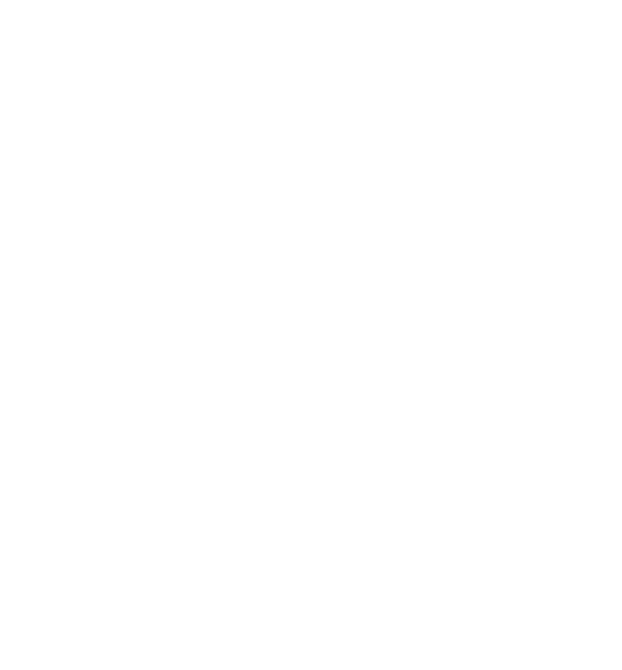
. 